\title{
Development in the Regulation of Wages and Working Conditions: The Employee Perspective
}

\section{Laust Høgedahl'}

Post doctoral researcher, Centre for Labour Market Research (Carma), Department of Political Science, Aalborg University

\section{Henning Jørgensen}

Professor Centre for Labour Market Research (Carma), Department of Political Science, Aalborg University

\begin{abstract}
The Nordic countries are renowned for their high level of unionization and collective bargaining. However, globalization, Europeanization, and an increasing individualization are often pictured as factors suppressing collective regulation. In this article, we look at the developments in the regulation of wages and working conditions from a macro perspective by combing two large crosssectional surveys into a longitudinal study with point of departure in the Danish case. We find that collective bargaining coverage continues to stand surprisingly strong, both in terms of being very widespread and in employee awareness, but Danish wage and salary earners also have an interest in extra support in the form of generalization and/or a politically regulated minimum wage.
\end{abstract}

\section{KEYWORDS}

Collective bargaining / collective agreements / industrial relations / labor market regulation / trade unions

DOI

10.18291/njwls.v7il.81393

\section{Danish Labor Market Regulation: Something Particular and Particularly Threatened?}

n Denmark-as in the other Nordic countries-there are lengthy traditions for collective regulations covering practically the entire labor market. Collective agreements define collective rights as opposed to individual rights, as in most other European and Anglo-American systems. Collective awareness and collective regulations count where collective agreement coverage exists. But are we approaching the end of the era of collective regulation? This would suggest many discussions, individualization theses (Beck et al., 1994; Atkinson, 2007; Berger \& Hitzler, 2010), new theoretical lenses like employment relations (Lewis et al., 2003, Kaufmann, 2004; Wilkinson et al., 2014), or theories with point of departure in contemporary comparative political economy (Gautié \& Schmitt, 2010; Stone \& Arthurs, 2013; Streeck, 2014). However, the Nordic countries are, on the other hand, often described as an outlier by displaying a high degree

\footnotetext{
${ }^{1}$ Laust Høgedahl, E-mail: hogedahl@dps.aau.dk
} 
of institutional stability in the changing world of work in spite of liberalization-and deregulation processes caused by an increasing international competition, globalization, and Europeanization (Thelen, 2009, 2014; Refslund \& Sørensen, 2016).

The institutional stability is often linked to a high degree of collective bargaining and collective representativity among both employers (in employer associations) and employee. Especially strong labor movements and social democratic parties and crossclass cooperation have traditionally been identified as important factors in this process (Korpi, 1989). This mirrors a close connection between the labor market system and the welfare system. Strategic choice theories often miss this point (Kochan et al., 1984; Poole, 1986; Sisson, 1987). Collective bargaining coverage and employee perception and attitudes toward collective institutions are good indicators on institutional stability or transformation. Hence, in this article, we investigate developments in the regulation of wages and working conditions seen from an employee perspective. The research questions guiding our investigation are:

- How has the collective bargaining coverage developed from 2002 to 2014 seen in relation to other forms of regulation?

- How do employees perceive labor market regulation? Is support for collective agreements still to be found or do employees now prefer other forms of regulation on the labor market?

The data used are based on two large Danish cross-sectional studies from 2002 and 2014 combined into a longitudinal design. The survey data allow us to survey the development in the collective bargaining coverage and at the same time investigate employee's preferences and attitudes toward different forms of labor market regulation. The article begins with methodological considerations linked to the study of labor market regulation from a macro-perspective, including the presentation of the data material upon which the analysis in hand is based. This is followed by an expanded theoretical explanation of the regulatory forms existing in the Danish labor market and the forces driving the regulation of wages and working conditions. The empirical analysis is then presented on the background of survey data. The article is rounded off with some concluding remarks by returning to the two research questions presented above.

\section{How is Labor Market Regulation to be Investigated Methodologically?}

The study of labor market regulation from a macro-perspective involves burdensome amounts of data, first and foremost because there are no central registers covering the collective bargaining agreements. Employer associations in Denmark do have statistics regarding their own members, but are left to speculate when it comes to unorganized employers (DA, 2015). One is left to try to get a lay of the land via representative survey or cross-sectional data (Scheuer, 1996, 1997). So, at the moment, there is no strong alternative to survey research when you want to have factual information as to the distribution and prevalence of people's experiences, preferences, assessments, and opinions (Weisberg, 2005, 2008). This is also the case regarding collective bargaining coverage.

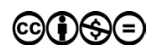


The design of surveys will have to take notice of some weaknesses as well, but you find no other instrument that more precisely will give answers to questions about a population, taking enough members of respondents to be able to generalize to the larger population of wage earners and trying to minimize nonresponse from people included in the sample.

This article draws on the so-called APL studies ${ }^{1}$, which have been carried out since 1992 by CARMA² (see Bild et al., 1993, 2007; Lassen et al., 2005; Caraker et al., 2014, 2015). The surveys have had these sample sizes: In 2002, 6000 persons were included; 2327 answered, giving a response rate of no less than 53.6. In 2014, 7047 persons were given a questionnaire that could be answered by post or by online survey (Evans \& Mathur, 2005), and 2831 full answers were recorded. The response rate reached $40.2 \%$. However, no serious bias in the material was discovered. The ways of generalizing results to the full population of Danish wage earners can be trusted.

By combining the two extensive cross-sectional studies from 2002 and 2014 (APL II and APL III) in a single longitudinal study, we are able to analyze employee responses in relation to experiences, values, and opinions regarding the regulation of wages/salaries and working conditions. This is made possible by the fact that the APL studies from 2002 and 2014 include a number of identical questions and response categories. As both studies are reasonably representative for the total active labor market force with respect to organizational factors, age, gender, and so forth, it is possible to compare the main areas (e.g., LO, FTF, AC, Lederne) ${ }^{3}$ and changes over time (Donsbach \& Traugott, 2008). ${ }^{4}$ The same applies at the sector level. This creates unique opportunities for analysis-also internationally. However, it is important to stress that statistical analyses of the different data sets can discover strong correlations, but these do not account for determinants of opinion differences. This is a theoretical task. But the longitudinal perspective gives us the opportunity to examine differences between groups of people, including both backgrounds and attitudes, and changes over time. We have done extensive examinations of connections of the 2002 and 2014 results and distributions and statistical tests have been performed all the way through.

The survey method is thus appropriate in relation to outlining a current image of the collective agreement coverage (the perceived, actual conditions); at the same time, the method makes it possible to uncover employee assessments and attitudes (opinion questions) to labor market regulation. The survey method is not infallible, however, also with respect to the study of labor market regulation. First, previous studies have revealed that many employees are not fully aware of the extent to which they are covered by a collective agreement or not, nor what a collective agreement actually means for their remuneration and working conditions (see Scheuer \& Madsen, 2000, 2002). However, we are able to add certain control questions enabling us to test the reliability of the collective bargaining coverage. This inconsistency test shows only a small percentage of the answers given in the survey regarding the collective bargaining coverage as questionable (below 2 pct.) (Caraker et al., 2015). Similar findings are found in previous studies (Scheuer, 2000).

In general, surveys also have a limitation in measuring individual opinions. Under real-world conditions, opinions are produced as part of collective learning processes. Here, focus group interviews might have been an alternative. As another kind of check and explanation in depth, we have conducted a number of individual interviews after the survey data have been collected and analyzed. In 2015-2016, 53 individual interviews have been made with respondents of the survey who have indicated that they were willing to participate in such interviews. The same procedure was used in 1992 and 
2002. Thus, we have another kind of validation of results by the help of the qualitative interviews and a further deepening of our understanding of possible explanatory links in the material. In this article, we do not use the qualitative interviews directly, as the 2015-2016 results will be published at the beginning of 2017 only.

But the survey method is obviously advantageous, however, as it provides a representative and comprehensive picture of the labor market, which in turn makes it possible to draw comparisons between technical and professional areas, sectors and not least over time. In the empirical investigations below, we have divided employees according to their professional and technical backgrounds divided on the main organization level or lack thereof.

\section{The Regulation of Labor Markets and the Danish Case}

How is the regulation of the labor market to be understood analytically and operationally? In terms of content, this is about identifying how the labor market functions as order-created processes and structures (Emerson, 1988). We are talking about the regulation of the labor market, where collective steps are taken to standardize behavior and/ or set the institutional framework to this end. Regulation can therefore be defined as a causal relationship between actors who are acting within an institutional framework and which can create negotiated order (Jørgensen, 2014).

In his seminal work Industrial Relations System, American economist John T. Dunlop (1958) describes how every 'industrial relations system' produces an 'outcome' consisting of a 'web of rules' determining and regulating wages and working conditions. 'The outcome' depends on a number of issues between employers, employees, and the state. The regulation of wages and working conditions thus takes place in a balance between the free capital and market forces, national and international legislation, and not least individual and collective agreements between the social partners. This makes for a rather complicated 'web of rules' comprising the regulation of wages and working conditions in the labor 'market'. Instead of pure market solutions, where price and volume are the only considerations, there is talk of a multiplicity of technical, political, and normative regulations. Today, however, the understanding must be changed and expanded. It is too narrow and one-dimensional with only three actors, homestatic system propositions, and rule-making institutions (Flanders, 1965; Clegg, 1983). It is necessary to operate with a more fluid determination of the actor system. The number of actors seeking and obtaining influence is increasing and no common ideology is to be found (Hyman, 1975; Salamon, 2000; Edwards, 2005; Rose, 2008). Power and interests are being re-interpreted and repositioned in a more intensified and changing labor market.

The balance of power between the labor market parties can be read in the 'output', that is, the agreements, legislation, and interaction. Collective agreements must be seen as rigid tracks left from the safeguarding of interests and power struggles. But there are always new labor market situations, new trends, new struggles, and new balances of power-and then the regulations shift. The model thus includes a plurality of actors, decisions, forms of governance, and restrictions. There is talk of a bybridization of the forms of regulation (Hansen \& Jørgensen, 2012). Double and triple regulation is central to understanding this phenomenon, as national and international political actors are also involved. Power is relational. This mean always relative, balanced.

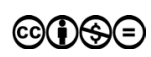


The political and labor-court framework that the state and labor market parties have worked together to develop serve as the basis for drawing sharper distinctions between six essentially different forms of regulation in the labor market:

1) Agreement-based regulation. The collective bargaining agreements reached between employers and employees regulate the material rights and obligations involved in the employment relationship. This also relates to the right to industrial action applying to both parties. The agreements are so-called 'area agreements'; that is, they apply to everyone working within a given area-unaffected by their trade union affiliation (Ibsen \& Jørgensen, 1979). The decentralization that has taken place in the Danish private sector in recent years has also made a difference in terms of which matters or areas are regulated via sector agreements or which ones require more specific agreements on the decentral/local level. Tied to this are the association-specific and local agreements (Due \& Madsen, 2008). Decentral agents have thus become more important in the system-particularly in the private sector. In the past, the main organizations played a greater and more decisive role. The agreement model plays closely together with the next regulatory model.

2) Cooperative regulation. This model for interaction is set in collective agreements but characterized by a local employer-employee partnership aimed at getting the everyday routine in the organization to function productively. Here, there is talk of 'good intentions' regulation, as there is no affiliated industrial action. This means that if employers qua their managerial authority say 'no', then the employee-side has no opportunity to (legally) apply sanctions. The key words in this form of regulation are therefore shared influence and participation by voluntary means (Caraker et al., 2014). However, the union representatives are able to make an impact on personnel policy, work environment measures, the climate for cooperation, and so forth in binding joint resolutions (participation) (Baadsgaard \& Jørgensen, 2014).

3) Legal regulation. This form of regulation is characterized by a set of rules determined by the state, which are to be followed by virtue of the state's monopoly on legislation. Here, behavior is standardized directly. Multiple forms of regulation are possible, which cover situations with legislation that can be waived (dispositive), if an agreement exists (semidispositive) or if such an agreement is ruled out (mandatory). Legislation can regulate all or parts of the labor market, including vacation time, maternity and paternity leave, as opposed to other areas that only apply to a specific group in the labor market, such as salaried employee's legislation and the Seaman's Act. Regulation, means of economic control, information, and public arrangements are among the management methods. As such, the authorities are also responsible for ensuring that the laws are complied with. The social partners have a penchant for legislation that may be waived if an agreement exists, which has become particularly relevant in the case of international regulation (particularly EU-regulation).

4) International legal regulation. As already mentioned in the Introduction, this form of regulation has become of increasing importance. This happens as international organizations such as the EU, UN, ILO, and the European Court of Human Rights have developed and expanded their provisions. This takes place in the form of EU legislation (regulations and directives), rulings from the European Court of Justice (ECJ), and so forth. This form of EU regulation is possibly posing the greatest challenge to the Danish (and Swedish) regulatory tradition, not only because it affects all 
employees but also because regulation preferably builds on constitutional traditions regarding politics and the courts as opposed to parliamentary traditions as we know them from the Scandinavian context. This means that the ECJ assumes an activist role in relation to the Danish labor market, as their 'case law' regulation is indispensable. EU law is over national law and collective agreements, and ECJ rulings have placed numerous restrictions on industrial action in recent years, especially the Laval-, Viking-, Rüffert-, and Luxembourg cases (Kristiansen, 2013).

5) Individual contract regulation. When employment relations are not regulated by a collective agreement, individual contracts can be reached between employer and employee. Here, the custom is to reach agreement on employment, wages, working conditions, dismissal procedures, and the conditions for carrying out the work. This form of regulation has increased dramatically in recent years, especially with respect to white-collar employees in the private sector (Scheuer \& Hansen, 2011). This form of regulation is preferred by many ideologically alternative trade unions (hereafter simply referred to as 'alternatives').

6) The exercise of managerial authority. In any employment relationship, the employer generally has the unilateral right to lay down the rules within the framework of managerial authority. The powers of instruction are extensive. In Denmark, the managerial authority of the employer has been established in $\$ 4$ of the so-called September Settlement (Septemberforliget) - the first ever general agreement in the world. This is based on the manager3ial authority, and if regulation has not been reached by other means, then the employer's instructions hold sway in terms of their right to manage and distribute work, to hire and fire, and to issue workplace regulations. This also creates advantages in interpretations in labor cases. All employees are thus covered by this form of management to some extent or another. In other words, it is basic.

These forms of regulation are specifically included in different constellations in Danish labor market regulation. The regulatory forms and the institutions supporting them complement one another; that is, they work together to produce certain and changing results. As such, there are no individual elements or fixed structures that produce the results but rather the manner in which the regulations have historically played together in constellations of power and regulations. The sum is more than the parts, but the parts are not fixed. However, the 'particularly Danish' consists of clear emphasis on agreement- and cooperation-based regulation compared with other countries (Lind et al., 2004). Here, the partners' preferences are unambiguous. Even though the employers have pressed for decentralization-particularly of wage formation-the technical and professional associations in Denmark have largely maintained and been able to maintain their right to make collective agreements in the process (Thelen, 2014).

As mentioned above, the balance between regulatory measures depends on a number of factors, including new labor market situations, cross-border movements of capital and labor, new trends, new struggles, and new power constellations. Such measures thus exist parallel to one another and in mutual bybrid connections. A number of different factors affect the relationship between the regulatory schemes, including fluctuating economic conditions, increased European integration, and the capacities of the social partners (Caraker et al., 2015a).

The economic and financial crisis since 2008 affected the balance of power between the social partners. It became a buyer's market, where many employees accepted cuts to 
their real wages if that was necessary to save their jobs, thinking that a smaller pay check beats none at all. Since 2008, the crisis has provided the inescapable backdrop that could clearly be read in the content in the agreements that have been reached (Caraker et al., 2015). Parallel to the economic cycles, other factors are also in play. Social dumping has received extensive media attention in recent years and genuinely concerns many employees, as documented by our APL III study (Caraker et al., 2014, 2015). However, macro factors such as the economic crisis and social dumping do not automatically lead to changes in labor market regulations (Coleman, 1986). The conditions are translated to experiences and attitudes among the stakeholders, not least including businesses and employees. Their perceptions, interests, desires, and requirements can help create change or ensure continuity. There is no determinism hanging in the balance.

It is therefore particularly interesting and relevant to ask employees what they think about the regulation of the labor market in addition to investigating the actual spreading of collective agreements in relation to other forms of regulation. The empirical analysis therefore investigates employee attitudes to 1) the collective agreement system, 2) individual agreements, 3) EU directives, 4) the generalization of agreements, and 5) government-set minimum wage. Before we consider the employee attitudes to regulatory reforms, we must first examine how the primary regulatory measure-that is, agreement coverage-has developed from 2002 to 2014.

As mentioned above, we concentrate our analysis on trade union affiliation divided by peak organizations. Traditionally, the Danish labor movement has been characterized by trade unions and professional organization organized and defined by trade (i.e., by type of training or education or by employment area) with relatively clear demarcation lines between them (cf. Scheuer, 1998); school teachers in The Danish Union of Teachers, electricians in The Danish Union of Electricians, etc (Ibsen et al., 2013). Thus, the external structure of the Danish can described as craft and to some degree general unionism (Clegg, 1976). These trade unions and professional organizations are for the most part members of one of the four peak organizations:

- LO (the Danish Confederation of Trade Unions): 17 member organizations representing around 843,000 workers. Organizing trade unions for skilled and unskilled workers, both blue color and white color, employed in both the public and private sector.

- FTF (the Confederation of Professionals in Denmark): 70 member organizations representing around 344,000 wage earners. Mainly public sector trade unions and professional organizations

- AC (the Danish Confederation of Professional Associations): 28 member organizations representing round 209,000 wage earners. Academic associations organizing members in both the private and public sector.

- Managers [Lederne] (The Danish Association of Managers and Executives): 1 organization presenting around 100,000 members (managers) in both the public-but mainly the private sector.

Some trade unions and professional are for some reason or the other not member of a peak organization but still conduct collective bargaining, for example, The Danish Union of Journalists. Around 60,000 wage earners are represented by trade unions with no peak organization affiliation. 
In addition to the 'traditional' labor movement described above, a number of socalled yellow or alternative unions exist in Denmark. The alternative unions are interdisciplinary organizing members across the board, that is, across different trades and professions in both the public and the private sectors. But the main feature that distinguishes the alternative unions from the traditional unions is their lack of use of collective action. The alternative unions do not engage themselves in collective bargaining activities with the employer side nor are they in favor of the use of strikes or any other collective actions, in fact, the statute-book of the Christian Union, the biggest alternative trade union, explicitly its members to strike (Høgedahl, 2014a). The alternative trade unions have around 250,000 members (for more on the rise of the alternative unionism in Denmark please see Ibsen et al., 2013; Høgedahl, 2014b). From 2002 to 2014, Denmark has seen a rise in the number of unorganized wage earners from around 750,000 to 810,000 (Høgedahl, 2014a). In combination with the rise of alternative unions, we might expect a lower collective bargaining coverage since there are fewer members of the traditional trade unions in 2014 and consequently fewer and weaker power resources.

\section{How has the Collective Agreement Coverage Developed?}

In 2014, the total collective bargaining coverage in Denmark was experienced to be $64 \%(A+C)$-in 2002, the figure was $65 \%$ (cf. Tab. 1). Somewhat surprisingly, the table

Table I Collective agreement coverage, by main areas, 2002, 2014 (\%)

Are your pay and employment conditions covered by a collective agreement, an individual contract or a combination of the two?

\begin{tabular}{lcccccccccccccc}
\hline & $\begin{array}{c}\text { A. } \\
\text { Collective } \\
\text { agreement }\end{array}$ & $\begin{array}{c}\text { B. } \\
\text { Individual } \\
\text { contract }\end{array}$ & $\begin{array}{c}\text { Combination } \\
\text { collective/ } \\
\text { private }\end{array}$ & $\begin{array}{c}\text { D. } \\
\text { no } \\
\text { agreement }\end{array}$ & \multicolumn{1}{c}{$\begin{array}{c}\text { Don't } \\
\text { know }\end{array}$} & $\begin{array}{c}\text { Collective } \\
\text { agreement } \\
\text { coverage } \\
\text { A+C C }\end{array}$ & N \\
\hline LO & $\mathbf{0 2}$ & $\mathbf{1 4}$ & $\mathbf{0 2}$ & $\mathbf{1 4}$ & $\mathbf{0 2}$ & $\mathbf{1 4}$ & $\mathbf{0 2}$ & $\mathbf{1 4}$ & $\mathbf{0 2}$ & $\mathbf{1 4}$ & $\mathbf{0 2}$ & $\mathbf{1 4}$ & $\mathbf{1 4}$ \\
FTF & 51 & 55 & 15 & 13 & 22 & 16 & 5 & 6 & 8 & 10 & 73 & 71 & 948 \\
AC & 71 & 70 & 6 & 5 & 18 & 18 & 2 & 4 & 3 & 3 & 89 & 88 & 512 \\
Managers & 50 & 48 & 26 & 20 & 11 & 16 & 10 & 12 & 3 & 3 & 61 & 64 & 342 \\
Without PO** & 13 & 14 & 56 & 50 & 23 & 15 & 9 & 19 & 0 & 3 & 36 & 29 & 116 \\
Alternatives & $*$ & 29 & $*$ & 45 & $*$ & 17 & $*$ & 5 & $*$ & 3 & $*$ & 46 & 58 \\
Non-members & 31 & 36 & 30 & 25 & 21 & 14 & 13 & 17 & 5 & 9 & 52 & 50 & 231 \\
\hline Total & 19 & 33 & 39 & 25 & 14 & 10 & 15 & 15 & 13 & 17 & 33 & 43 & 508 \\
\hline
\end{tabular}

Source: APL II (2002) and APL III (20|4).

*Low significance.

***Traditional trade unions but not associated to any peak organization. 
Table 2 Attitudes to labor market regulation, main areas, 2014 (\% totally/partially agree)

I) Pay and working conditions should be regulated through collective agreements made by trade unions and employer associations.

2) Pay and working conditions should exclusively be agreed to between the individual employee and employer

3) EU directives should be regulating pay and working conditions to a higher degree

4) The authorities should help ensure that collective agreements are spread to nonorganized workplaces (generalization)

5) The Folketing should pass legislation to establish a minimum wage that applies for the entire labor market

\begin{tabular}{lllllll}
\hline & $1)$ & $2)$ & $3)$ & $4)$ & $5)$ & $\mathrm{N}$ \\
\hline LO & 81 & 28 & 8 & 45 & 51 & 938 \\
FTF & 89 & 18 & 7 & 47 & 49 & 511 \\
AC & 74 & 27 & 10 & 48 & 52 & 336 \\
Managers & 47 & 57 & 7 & 36 & 47 & 115 \\
Without PO* & 56 & 46 & 2 & 27 & 45 & 57 \\
Alternatives & 55 & 44 & 9 & 41 & 55 & 231 \\
Nonmembers & 51 & 47 & 7 & 36 & 53 & 478 \\
\hline Total & $\mathbf{7 2}$ & $\mathbf{3 3}$ & $\mathbf{8}$ & $\mathbf{4 4}$ & $\mathbf{5 1}$ & $\mathbf{2 6 6 6}$ \\
\hline
\end{tabular}

Source: APL III (20|4).

Note: The five questions are included in the same battery. Question used: How do you think the labor market should be regulated? The respondents were given five response categories based on a Likert scale:Totally agree, partially agree, Do

not agree or disagree, partially agree, totally disagree.

* Traditional trade unions but not associated with any peak organization.

thus shows that the total collective agreement coverage from 2002 until 2014 is constant. In 2014, $18 \%$ of the respondents answered that they have an individual contract, $9 \%$ have no agreement and $9 \%$ do not know what kind of an agreement they have.

There are significant differences between the main groups. This must be seen in the context of how the main groups are represented differently in the private and public sectors. Like the managers, many of the alternatives and nonmembers are working without any agreement. For the managers, the percentage is $19 \%$, and it is $17 \%$ and $15 \%$ for the alternatives and nonmembers, respectively. Further differentiation is found among the nonmembers group. Further analysis shows that collective agreement coverage decreases with the length of education: Only $29 \%$ of the nonmembers with a university degree have a collective agreement, while $64 \%$ have an individual contract or no agreement at all. By main area, we find great continuity from 2002 until 2014.

\section{Employee Attitudes to Labor Market Regulation}

Table 2 illustrates the preferences and attitudes among employees to labor market regulation on the basis of the responses ( $\%$ of totally/partially agree) to five questions. The first 
question is about collective agreements. Here, there is a clearly positive balance of opinion in all of the main groups, apart from the leaders. The unconditional support is high in FTF and LO (89\% and $81 \%$, respectively), while it is rather lower among the managers $(47 \%)$, the alternatives $(55 \%)$, and nonmembers $(51 \%)$. It is also in the latter three groups that most are opposed. It is worth noting how $55 \%$ of the alternative members actually have a preference for regulation through collective agreements. This stands in contrast to the alternative trade unions, which are decidedly against the main components in the Danish model.

The response pattern makes clear that there is broad support for the agreement regulation. It also shows that the form of regulation being used would appear to be generally preferable-although in such a manner that many employees with individual contracts or no agreements $(48 \%$ and $45 \%$, respectively) are also in favor of the collective system. The response pattern means that there are differences from sector to sector. Larger percentages of the managers, alternatives, and nonmembers work with individual contracts/ no agreements; here, support for collective bargaining is correspondingly lower.

As mentioned above, an alternative means of regulation to the general collective model is that wages and working conditions are reached via written or unwritten individual employment contracts. There is very limited support for such agreement conditions (cf. Tab. 2). The individual agreements are supported by a total of $33 \%$ of the employed individuals, while $44 \%$ are against; in other words, a clearly negative balance of opinion.

There are major differences between the main groups. A total $57 \%$ of the managers, $47 \%$ of the nonmembers, and $44 \%$ of the alternatives support the individual model, while this is only the case for $18 \%$ of the FTFs and LO in an intermediate position, for a total of $28 \%$.

The $33 \%$ supporting the individual model might well appear surprisingly high considering the response pattern above regarding the agreement system and when considering the unconditional wording of the question 'should only be agreed between' the individual and their employer. There are no alternative conditions that can cast light on the differences between the main groups. The employees with private or no agreements represent $43 \%$ of the total support and $51 \%$ of the 'totally agree' support. Main groups that include a relatively larger percentage of employees with individual contracts/no agreement therefore have higher support percentages for the individual model.

A mere $7 \%$ find that EU directives should be playing a more prominent role with respect to regulating the employment relationship. The balance of opinion is thus clearly negative. The difference between the groups is limited, with the managers being the most con and the nonmembers the most pro. The lengthy historical tendency among employees to link national sovereignty with social questions and union policy rights would thus appear to be confirmed. The majority do not attribute decisive significance to the EU directives that have improved a number of rights on individual questions or they are against the legalization of the EU. There would appear to be tension in relation to Danish agreement regulation, where increasingly strong, de facto international influence is making itself felt on Danish labor market regulation-a development that employee groups do not welcome.

Generalization involves possible help from the state to render collective agreements more widespread and respected. This provision means that it is the employer association and specific union organization with the dominant collective agreement on the given area of trade that will 'generalize' the agreement to prevent underbidding; they will receive assurances from the state that this agreement also applies to the companies operating in the same area that are not covered by the collective agreement. In that case, the authorities

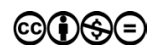


help enforce the generalized provisions (as in Norway, Finland, and Iceland). Still, this is not introducing Erga Omnes clauses that makes a collective agreement generally binding within its field of application by explicitly binding all those employees and employers who are not members of the parties to the agreement. In Denmark, the debate about generalization is relatively recent and presumably has not spread throughout the common members in the trade unions (although see Ibsen, 2011; LO, 2011; Moos, 2012), while Erga Omnes is well known in other European countries (Riberio, 2016). Generalization is supported by a total of $44 \%$. The difference between the main groups is not very great. The predominantly strong support to generalization is therefore also present among the alternatives and nonmembers. The 'against' share would appear to be slightly greater among the managers $(41 \%)$ and nonmembers $(31 \%)$. Almost half of LO's members $(45 \%)$ are in favor of generalization, almost twice the number of those against $(23 \%)$. This is interesting in relation to the fact that the LO do not want generalization (Ibsen, 2011). The responses might therefore have been given on the basis of the employees' own experiences and how they feel the agreement system can be rendered future-proof. Social dumping is motivating the support for the collective agreement system (Caraker et al., 2015).

Similarly, positive attitudes are found in the responses about the possible introduction of a state-enforced minimum wage. A total of $51 \%$ of the employees will accept a government-set minimum wage, while $25 \%$ total are against. These percentages are rather surprising when considering the high percentage simultaneously supporting the collective agreement system. There are no major differences between the main groups. In total, around half of the members in most of the main groups support a state-set minimum wage, the alternatives and nonmembers mustering the largest shares (total 55\% and $53 \%$, respectively). The managers stand out in terms of having the highest percentage against (total 35\%). A large percentage of LO's members $(51 \%)$ support a state-set minimum wage even though the central organization is against a state-set minimum wage. The LO sees a contradiction between a partner-regulated system and state labor market regulation (as this renders it impossible to use the instruments of labor law), but most members do not share this view.

Overall, it must be concluded that the majority of members do not see generalization and a state-set minimum wage as being opposed to the agreement system but rather as possible supplements. Most union members do not have reservations towards state assurances or the 'galvanization' of the collective agreement system, nor do they distinguish between the means to ensure the system like the union organizations do (Ibsen, 2013). Further analyses reveal that $53 \%$ of those supporting the agreement model also support generalization, while $56 \%$ of those supporting the agreement model also support a state-set minimum wage (Caraker et al., 2015).

\section{The Stability and Continued Legitimacy of Labor Market Regulation}

This article has examined the development of labor market regulation in Denmark, including how collective agreement coverage has developed from 2002 until 2014, while at the same time investigating which forms of regulation employees themselves prefer.

Now, we can conclude in relation to the research questions guiding our investigation: How has the collective bargaining coverage developed from 2002 to 2014 seen 
in relation to other forms of regulation? And how do employees perceive labor market regulation? Is support for collective agreements still to be found or do employees now prefer other forms of regulation on the labor market?

First, we can conclude that agreement coverage in the private sector has been remarkable stable from 2002 until 2014. And, the public sector is still fully covered. There is no erosion of the Danish labor market regulation model in this respect.

But the constancy of agreement coverage reveals that the unions that have reached collective agreements with the employers have managed to maintain collective agreements in the private labor market despite generally falling membership figures, economic crises, and an increased internationalization with increased employer flexibility as a result. The employees who are only subjected to the market forces without collective agreements or individual agreements are constant from 2002 until 2014.

When it comes to attitudes to different regulatory measures in the Danish labor market, there is still comprehensive support for the collective agreement model. This is also the case for many of the members of the alternative unions and nonmembersdespite the fact that these employees do not contribute actively to the maintenance of the agreement model through membership of an agreement-bearing union. We can generally say that there is a connection between the form of regulation to which employees are subjected and the form of regulation that is preferred.

We also found that many employees believe that the agreement model can be supplemented with generalization mechanisms and/or a state-set minimum wage. Generalization and the minimum wage are not viewed by the employees as an actual alternative to the agreement model but rather as a supplement or support in difficult times with social dumping mushrooming.

The Nordic countries all have strong unions and employer organizations, comprehensive collective bargaining coverage, but there are big differences as to the way of handling collective agreements after they have been made. Systematically, Finland and Iceland generalize their collective agreements, and Norway has followed in a number of branches since 2004. In Denmark and Sweden, there are no Erga Omnes clauses and no public support for generalizing collective agreements. Thus, social dumping calls for stronger professional monitoring and regulation as well as unionization campaigns in these two countries, and it is much more difficult to give politicians more important roles as to regulation than is the case in Norway (without a Ghent system of unemployment insurances) and the other Nordic countries. To accept a minimum wage-as happened in Germany as from January 1, 2015-by the side of the labor market organization elites is simply impossible in Denmark and Sweden. This would imply that the collective weapons of strike and lockout would be illegal and that politicians partially would be substituting the leadership of the labor market organizations as central decision-makers.

The legitimacy at the core of the Danish labor market regulation-agreementbased, conflict partner regulation and a model for collaboration-is not threatened, not even weakened over time. On the contrary, the new economy and the internationalized conditions for reaching agreements between the organizations on the labor market have brought new actors and more arenas into this regulation, thereby developing the IR system, but they have not provided the employees with experience and assessments that encourage the 'scrapping' of elements in the labor market system. The Danish model is fully alive and well in the minds of the employees and in the continued adaptation of the agreement and collaboration model to the new surroundings. Conversely, there are

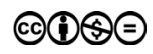


increasing problems with domestic political and international regulation-particularly EU regulation-which interferes with the claimed voluntarism in the Danish labor market. Even the most basic practices, institutions, and ideas of industrial relations are given different shape and meaning across countries or groups of countries. Globalization and years of economic crisis do not change this. Surprisingly, our Danish case material witness no path breaking developments. Collective and voluntary labor market regulation and traditional conflict resolution is strongly supported by wage earners.

\section{References}

Atkinson, W. (2007). 'Beck, individualization and the death of class: a critique'. The British journal of sociology, 58(3), 349-366.

Beck, U. et al. (eds.) (1994). Reflexsive Modernization, Polity Press, Cambridge.

Berger, P. A., \& Hitzler, R. (2010). Individualisierungen. Springer Fachmedien.

Bild, T. et al. (1993). Foellesskab og forskelle [Community and differences], LO and CARMA, Copenhagen.

Bild, T. et al. (2007). Arbejdsliv og politik - signalement af lønmodtagere $i$ det 21. århundrede [Working life and policy - description of employees in the 21st century], Nyt fra Samfundsvidenskaberne, Copenhagen

Borchorst, A., Caraker, E. and Jørgensen, H. (2012). 'Den Danish model i knibe - også for analytisk potentiale?' [The Danish model in a pinch - even for analytical potential?], pp. 82-104 i Tidsskrift for Arbejdsliv, vol. 14, no. 2.

Caraker, E. et al. (2015). Follesskabet før forskellene [The community before the differences], LO og FTF, Copenhagen, 2015.

Caraker, E. et al. (2014). Follesskab for forskelle [The community before the differences], LO and FTF, Copenhagen, 2014.

Caraker, E.: (2008). Industriarbejdere mellem tradition og forandring - om interesser og loereprocesser blandt Danish industriarbejdere [Industrial workers between tradition and change - about interests and learning processes among Danish industrial workers], Ph.d. afhandling. Aalborg Universitet, Aalborg.

Clegg, H. A. (1976). Trade Unionism under Collective Bargaining. London: Blackwell.

Clegg, H. A. (1983). Trade unionism under Collective Bargaining: A Theory based on Comparisons of Six Countries, Blackwell, Oxford.

Coleman, J. S. (1986). 'Social theory, social research, and a theory of action', pp. 1309-1335 in American Journal of Sociology.

Donsbach, W. and Traugott, M. W. (eds.) (2008). The SAGE Handbook of Public Opinion Research, Sage, London.

Due, J., Madsen, J. S. and Jensen, C. S. (1994). The survival of the Danish Model - A Historical Sociological Analysis of Collective Bargaining, DJØF Publishing, Copenhagen

Due, J., Madsen, J. S. and Jensen, C. S. (1993). Den Danish Model - En historisk sociologisk analyse af det Danish aftalesystem [The Danish model: A historical sociological analysis of the Danish agreement system], DJØF Publishing, Copenhagen.

Dunlop, J. T. (1958). Industrial relations systems, Holt, New York.

Edwards, Paul (ed) (2005). Industrial Relations. Theory and Practice, 2. Ed., Blackwell, London.

Emerson, M. (1988). Regulation or deregulation of the labour market: Policy regimes for the recruitment and dismissal of employees in the industrialised countries. European Economic Review, 32(4), 775-817.

Evans, J. R. and Mathur, A. (2005). 'The value of online surveys', pp. 195-219 in Internet research, vol. 15 , no. 2 . 
Flanders, Allan (1965). Industiral Relations: What is Wrong with the System?, Farber \& Farber, London.

Fox, Allan(1966). Industrial Sociology and Industrial Relations, HMSO, London.

Gautié, J., \& Schmitt, J. (Eds.). (2010). Low-wage work in the wealthy world. Russell Sage Foundation.

Hansen, L. B. and Jørgensen, H. (2012). 'Den Danish model' belyst ved lønmodtagernes erfaringer og holdninger 2011 ['The Danish model' illuminated by employees' experiences and opinions 2011], LO-dokumentation nr. 2, LO, Copenhagen.

Hyman, R. (1975). Industrial Relations: A Marxist Introduction, Macmillan, London.

Høgedahl, L. (2014a). Fagforening på markedsvilkår: Markedsgørelse af den faglige organisering og nye vilkår for kollektiv handling på det danske arbejdsmarked. Aalborg Universitetsforlag. (Ph.d.-serien for Det Samfundsvidenskabelige Fakultet, Aalborg Universitet). doi: http://dx.doi.org/10.5278/vbn.phd.socsci.00010.

Høgedahl, L. (2014b). The Ghent effect for whom? Mapping the variations of the Ghent effect across different trade unions in Denmark. Industrial Relations Journal, 45(6), 469-485.

Ibsen, F. (2012). 'Almengørelse af overenskomsterne: Et støtteben til den Danish model?' [Generalization of collective agreements: Support to the Danish model?], pp. 67-81.

i Ibsen, F., Høgedahl, L., \& Scheuer, S. (2013). Free riders: The rise of alternative unionism in Denmark. Industrial Relations Journal, 44(5-6), 444-461.

Kochan, T. A., Katz, H. C., \& McKersie, R. B. (1986). The transformation of American industrial relations. Cornell University Press.

Korpi, W. (1989). Power, politics, and state autonomy in the development of social citizenship: Social rights during sickness in eighteen OECD countries since 1930. American sociological review, 309-328.

Jørgensen, Henning (ed.) (2014). Arbejdsmarkedsregulering (Labour market regulation), Jurist- og Økonomforbundets Forlag, København.

Kaufmann, Bruce E. (ed) (2004). Theoretical Perspectives on Work and the Employment Relationship, University of Illinois, Champaign.

Kochan, Thomas A. et al. (1984). 'Strategic Choice and Industrial Relations' pp. 16-39 in Industrial Relations, vol. 23, no. 1.

Kristiansen, Jens (2013). Aftalemodellen og dens europaiske udfordringer: Om rollefordelingen mellem overenskomstparterne, Folketinget og domstolene [The agreement model and its European challenges: On the roles between the agreement partners, the Folketing and the courts], DJØF Publishing, Copenhagen.

Lewis, P. Thornhill, A. and Saunders, M. (2003). Employee Relations - Understanding the employment relationshiop, Prentice-Hall, Essex.

LO (2011). Rapport fra udvalget om social dumpning [Report from the committee on social dumping], LO, Copenhagen.

Moos, Bent (2012). 'Almengørelse af overenskomster - lovsikret almengørelse kan være et redskab i kampen mod social dumpning' [Generalization of collective agreements: legally secured generalization can be an instrument in the fight against social dumping], pp. 105-116 i Tidsskrift for Arbejdsliv, 14. årg., nr. 2.

Møberg, R., Bay, T. and Lassen, M. (2005). Lønmodtagerne i tiåret 1992-2002 - Konstans eller forandring? [Employees in the decade 1992-2002 - constancy or change], LODokumentation, Copenhagen.

Poole, M. (1986). Industrial Relations - orgins and patterns of national diversity, Routledge \& Kegan Paul, London.

Refslund, B., \& Sørensen, O. H. (2016). Islands in the stream? Challenges and resilience of the Danish industrial relations model in a liberalising world. Industrial Relations Journal, 47(5-6), 530-546. 
Ribeiro, Ana Teresa. 'Recent Trends in Collective Bargaining in Europe.' E-Journal of International and Comparative Labour Studies 5.1 (2016).

Rose, Ed (2008). Employment Relations, $3^{\text {rd }}$ ed., Pearsons Education, London.

Salamon, Michael (2000). Industrial Relations Theory and Practice, $4^{\text {th }}$ ed., Perasons Education, London.

Scheuer, S. (1997). Arbejdstid og overenskomst: En arbejdssociologisk analyse af kollektive overenskomsters betydning for privatansattes arbejdstid og overarbejde [Labour and collective bargaining: a labour sociological analysis of the significance of collective agreements for the working hours and overtime for employees in the private sector]. Nyt fra Samfundsvidenskaberne, Copenhagen.

Scheuer, S. (1996). Foelles aftale eller egen kontrakt $i$ arbejdslivet: Udbredelsen af kollektive overenskomster, faglig organisering og skriftlige anscettelsesbeviser blandt privatansatte [Common agreements or private contracts at work: The prevalence of collective agreements, union organization and written proof of employment among private sector employees], Nyt fra Samfundsvidenskaberne, Copenhagen.

Scheuer, S., \& Hansen, K. R. (2011). Funktionærloven: En lønmodtagerlov for de fleste? [The Salaried Employees Act: A labour act for most?]. Samfundsoekonomen, (2), 24-31.

Sisson, Keith (1987). The Management of Collective Bargaining - An International Comparison, Blackwell, Oxford.

Stone, K. V., \& Arthurs, H. (Eds.). (2013). Rethinking workplace regulation: Beyond the standard contract of employment. Russell Sage Foundation.

Streeck W (2014) Buying Time: The Delayed Crisis of Democratic Capitalism. London: Verso.

Sørensen, Villy (1992). Den frie vilje - Et problems historie [Free will - the history of a problem], Hans Reitzels Forlag, Copenhagen.

Thelen, K. (2009). Institutional change in advanced political economies. British Journal of Industrial Relations, 47(3), 471-498.

Thelen, K. (2014). Varieties of liberalization and the new politics of social solidarity, Cambridge University Press, Cambridge.

Weisberg, Herbert F. (2008). 'The Methodological Strength and Weaknesses of Survey Research', pp. 223-231 in Donsbach and Traugott (2008). The SAGE Handbook of Public Opinion Research, Sage, London.

Weisberg, Herbert F. (2005). The total survey error approach: A Guide to the new science of survey research, Chicago University Press, Chicago.

Wilkinson, A., Wood, G. and Deeg, R. (eds.) (2014). The Oxford Handbook of Employment Relations: Comparative Employment Systems, Oxford University Press, Oxford.

\section{Notes}

${ }^{1}$ Arbejdsliv and Politik set $i$ et Lønmodtagerperspektiv - Working life and politics seen from the employee perspective.

2 The Centre for Labour Market Research, Institut for Political Science, Aalborg University, AAU.

${ }^{3}$ LO (the Danish Confederation of Trade Unions), FTF (the Confederation of Professionals in Denmark), and AC (the Danish Confederation of Professional Associations), Lederne (The Danish Association of Managers and Executives). Corresponding peak organizations are found the other Nordic countries: Sweden LO, TCO, SACO; Norway: LO, YS, Union, Akademikerne; Finland: SAK, STTK, AKAVA.

${ }^{4}$ Please see Bild et al., 2007; Caraker et al., 2015 for more on the pretesting, validity, and reliability of the two surveys. 